\title{
Gas-Particle Partitioning of Polychlorinated Dibenzo-p-dioxins, Dibenzofurans, and Biphenyls in Flue Gases from Municipal Solid Waste Incinerators
}

\author{
Ying Han ${ }^{1,2}$, Wenbin Liu ${ }^{1,2 *}$, Haifeng $\mathrm{Li}^{1,2}$, Rongrong Lei ${ }^{1,2}$, Lirong Gao ${ }^{1}$, Guijin $\mathrm{Su}^{1}$, \\ Guorui Liu ${ }^{1}$ \\ ${ }^{I}$ State Key Laboratory of Environmental Chemistry and Ecotoxicology, Research Center for Eco-Environmental Sciences, \\ Beijing 100085, China \\ ${ }^{2}$ University of Chinese Academy of Sciences, Beijing 100049, China
}

\begin{abstract}
Gas-particle partitioning of polychlorinated dibenzo-p-dioxins, dibenzofurans (PCDD/Fs), and biphenyls (PCBs) was evaluated in flue gases emitted from two municipal solid waste incinerators. Total PCDD/Fs and dl-PCBs in the flue gas were presented, in decreasing order, within gas phases, particulate phases, and aqueous phases. PCDD/F concentrations in the flue gas ranged from 0.75 to $15 \mathrm{ng} \mathrm{m}^{-3}$, while in the particulate phase they ranged from 0.14 to $8.1 \mathrm{ng} \mathrm{m}^{-3}$. Dioxin-like (dl-) PCBs had concentrations of $0.18-28 \mathrm{ng} \mathrm{m}^{-3}$ in the flue gas, and $0.041-1.3 \mathrm{ng} \mathrm{m}^{-3}$ in the particulate phase. PCDD/F and dl-PCB levels were associated with specific size ranges of particles, increasing as particle size decreased. More than $54 \%(81 \%)$ of PCDD/Fs and 49\% (79\%) of dl-PCBs were associated with fine particles of less than $2.5(10) \mu \mathrm{m}$-diameter. In addition, average levels of PCDD/Fs, PCBs, and dl-PCBs were $0.15 \pm 0.11 \mathrm{ng} \mathrm{m}^{-3}, 11 \pm 11 \mathrm{ng} \mathrm{m}^{-3}$, and $0.21 \pm 0.20 \mathrm{ng} \mathrm{m}^{-3}$, respectively. Levels of non-2,3,7,8-chlorinated PCDD/Fs were much higher than 2,3,7,8-chlorinated PCDD/Fs in PCDD/F homologue patterns. This suggests that more attention should be paid to non-2,3,7,8-chlorinated PCDD/Fs in the environment, given their potential to transform to more toxic species.
\end{abstract}

Keywords: $\mathrm{PM}_{2.5}$; Haze; MSWIs; Gas-particle-water partitioning; Non-2,3,7,8-PCDD/Fs.

\section{INTRODUCTION}

Incineration is commonly used around the world as an effective, sanitary and practical method of waste disposal, leading to the establishment of more municipal solid waste incinerators (MSWIs) (Zhang et al., 2014). A total of 50.1 million tons of municipal solid waste was incinerated in China in 2013 (a 33\% increase over the last decade) (Han et al., 2016a; Meng et al., 2016), becoming an important emission source of polychlorinated dibenzo-p-dioxins and dibenzofurans (PCDD/Fs) (Xu et al., 2009; Li et al., 2012; Li et al., 2016), as well as dioxin-like compounds such as polychlorinated biphenyls (PCBs) (Guo et al., 2014). Concentrations of PCDD/Fs and PCBs released in flue gases from MSWIs primarily increase with increasing incineration temperature, and are typically adsorbed onto atmospheric particles (Cetin et al., 2017). PCDD/Fs and PCBs emission from the incinerators had been proved to be harmful for human health (Yu et al., 2016). Given the high frequency

\footnotetext{
*Corresponding author.

Tel.: +86-10-62849356; Fax: +86-10-62923563

E-mail address: liuwb@rcees.ac.cn
}

of occurrence for serious haze-fog events and severe air pollution in China, characterizing the spatial distributions of such contaminants in the atmosphere, especially in the particulate phase, has become a focus of research.

PCDD/Fs and PCBs released from the flue gas can spread through air, soil, water bodies, sediments, and enter plant and animal systems through atmospheric deposition (Du et al., 2011; Suryani R et al., 2015; Chang et al., 2016). They occur as both gas and particulate phases in the atmosphere. On undergoing gas-particle partitioning in the atmosphere, PCDD/Fs and PCBs tend to combine with particles and be deposited (Li et al., 2008; Wu et al., 2009; Zhang et al., 2016; Zhu et al., 2016). Fine particles (with aerodynamic diameter (D) less than $2.5 \mu \mathrm{m} ; \mathrm{PM}_{2.5}$ ) have longer atmospheric lifetimes in the atmosphere than larger ones, and a higher ability to adsorb and retain PCDD/Fs and PCBs, because of their larger specific surface areas and more porous surfaces (Zhu et al., 2016).

Kaupp and McLachlan measured most PCDD/Fs in particles less than $2.9 \mu \mathrm{m}$ in size (Kaupp and McLachlan, 2000). Chao et al. (2003) investigated the particle size distributions of PCDD/Fs in the atmosphere with $\mathrm{D}$ between 0.056 and $100 \mu \mathrm{m}$, and found over $80 \%$ of PCDD/Fs bound to fine particles $(\mathrm{D}<2.0 \mu \mathrm{m})$. Most previous studies of PCBs focused on atmospheric distributions (Chrysikou 
et al., 2009; Chrysikou and Samara, 2009), and PCBs emitted as gas from various sources (Baek et al., 2010). To date, there have been few studies of particle-bound PCBs and their size distributions. Some studies have reported polychlorinated naphthalene and polycyclic aromatic hydrocarbon distributions in different particle sizes; these compounds also are preferentially associated with smaller particles (Kaupp and McLachlan, 2000; Zhu et al., 2016). Wei et al. detected high concentrations of low-chlorinated PCDD/Fs in smaller particles (Wei et al., 2016). Yu et al. found that $\mathrm{PM}_{2.5}$ contributed most to haze formation in regions where the population suffers most adverse health effects (Yu et al., 2014). And a strongly relationship between particulate matters in the atmosphere and some kinds of diseases was concluded (Zhu et al., 2017). Such health effects appear to increase, as particle size decreases (Kurogawa et al., 1998). Consequently, the size distribution properties of aerosol particles could reflect the characteristics of pollution (Yu et al., 2017).

The persistence and lipophilicity enhance the ability of accumulation of PCDD/Fs and PCBs in the environment for many years (Chi et al., 2016). Thus the existence of relatively non-toxic dioxin congeners (non-2,3,7,8-substituted $\mathrm{PCDD} / \mathrm{Fs}$ ) in the environment should also be considered. Some relevant studies have investigated the metabolizing effects of 1,2,3,4-TCDD (Hanioka et al., 1994), 1,3,7,8TCDD (Petroske et al., 1997) and 1,2,7,8-TCDD (Hakk et al., 2001) in rats. In particular, 1,2,3,4-TCDD induced the activities of metabolizing enzymes and enzyme proteins at different doses (Hanioka et al., 1994). Hakk et al. (2001) detected 1,2,7,8-TCDD in all tissue types of the rat model. Petroske et al. (1997) found that 1,3,7,8-TCDD could be metabolized into 2-OH-1,4,7,8-TCDD and 3-OH-1,2,7,8TCDD in rats. As a result, the presence of non-2,3,7,8substituted $\mathrm{PCDD} / \mathrm{Fs}$ could influence various functions in living organisms.

The aim of our present study is to determine the gasparticle-water partitioning of PCDD/Fs and PCBs in the flue gas emitted from typical MSWIs. In addition, concentrations of non-2,3,7,8-substituted gas-phase PCDD/Fs were measured. To the best of our knowledge, this study provides the first extensive data set showing size-specific particle distributions of PCDD/Fs and PCBs in flue gases. Such data expand our current understanding of their transportation within the environment, and the relationships between sources and sinks of PCDD/Fs and PCBs. It is imperative to determine the concentrations and size-specific distributions of $\mathrm{PCDD} / \mathrm{Fs}$ and PCBs in various emission sources to provide reliable baselines for atmospheric monitoring.

\section{MATERIAL AND METHODS}

\section{Sampling}

Two typical MSWIs (A and B) with furnace incinerators were selected in this study. Both of them have treatment capacities of 600 tons of solid waste per day. A series of flue gas samples (25) were collected from June 2015 to July 2016 with size separated particulate sampler, which was an Isostack Basic isokinetic sampling system and a low volume aerosol sampler (TCR sampler; Tecora Corp., Milan, Italy) (Ba et al., 2009; Du et al., 2010). Thus, the gas phase, particulate phase, and water fractions were collected simultaneously. Five sample sets (S1-S5) were collected. S1 and S2 were collected from MSWI A (before and after updating its bag filter, respectively), while S3, S4 and S5 were from MSWI B. The volume of each air sample was about $4 \mathrm{~m}^{3}$ and each condensed water sample was around $60 \mathrm{~mL}$. In each set, one gas phase fraction was collected using the Isostack Basic isokinetic sampling system equipped with resin and three particulate phase fractions (D $>10 \mu \mathrm{m}$; $10 \mu \mathrm{m} \geq \mathrm{D}>2.5 \mu \mathrm{m}$; and $\mathrm{D} \leq 2.5 \mu \mathrm{m})$ were collected using the low volume aerosol sampler, equipped with one quartz fiber filter to collect particles between 2.5 and 10 $\mu \mathrm{m}$; the other two particulate fractions were wiped down with absorbent cotton (Fig. 1). It was difficult to accurately weigh particles adsorbed onto the filter or cotton, as they were lightweight. As a result, concentrations of PCDD/Fs and PCBs in particles were calculated based on the volume of sampled flue gas. The sampling flow rate was constant at $16.5 \mathrm{~L} \mathrm{~min}^{-1}$. Before and after sampling, the filters for collecting particle samples were weighed to reading precision. All parts of the sampler were cleaned with methanol, acetone

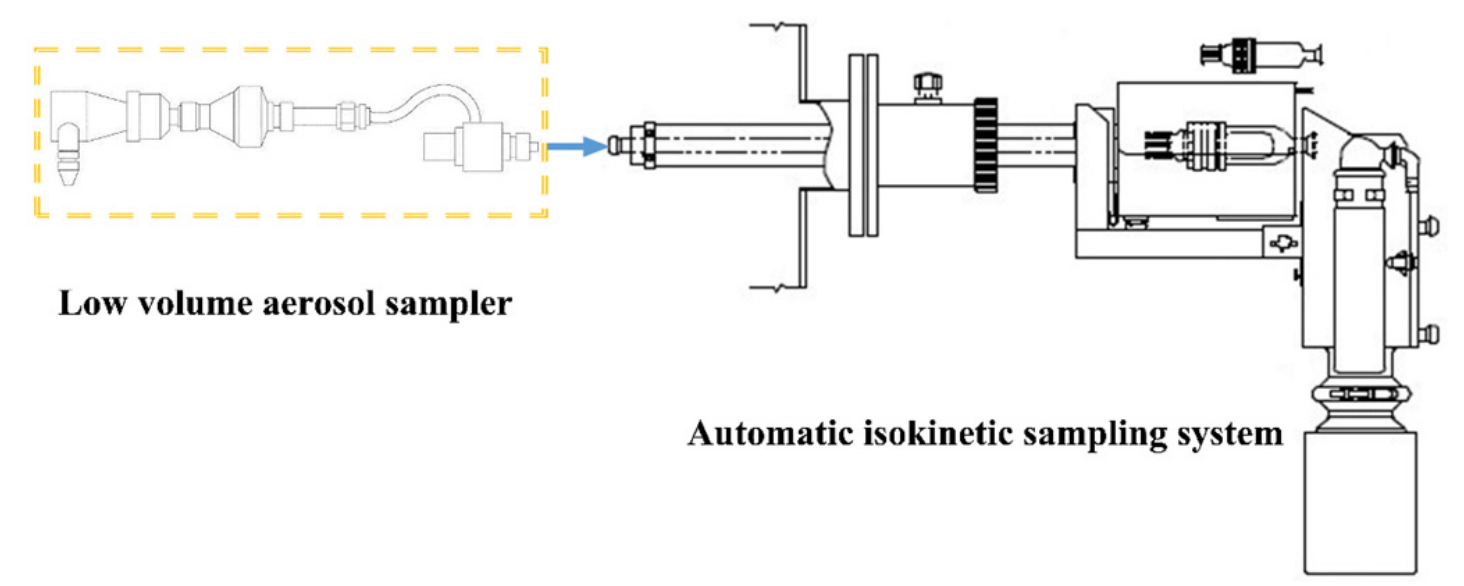

Fig. 1. Schematic diagram showing the Isostack Basic isokinetic sampling system, equipped with a low volume aerosol sampler. 
and dichloromethane successively after sample collection. Samples were wrapped in aluminum foil, sealed in PVC bags, and stored in a refrigerator at $-18^{\circ} \mathrm{C}$ until analysis.

\section{Analytical Procedures}

Samples were analyzed for PCDD/Fs and PCBs using US EPA Method 1613 and 1668A (Hu et al., 2013; Han et al., 2016b). Briefly, gas and particulate phase samples were extracted with $250 \mathrm{~mL}$ of toluene (pesticide grade) using Soxhlet extraction for $24 \mathrm{~h}$. Condensed water samples were extracted with $90 \mathrm{~mL}$ of dichloromethane $(30 \mathrm{~mL}$ for each repetition). Each sample was spiked with ${ }^{13} \mathrm{C}$-labeled solutions of EPA-1613LCS and EPA-1668LCS (Wellington Laboratories, Guelph, Canada) as internal standards, before extraction. The extract was concentrated to a small volume and applied to a multilayer silica column and a basic alumina column to separate PCDD/Fs from PCBs. The final extract was concentrated to $20 \mu \mathrm{L}$ under nitrogen flow and spiked with ${ }^{13} \mathrm{C}$-labeled PCDD/F injection standards EPA-1613IS and EPA-1668IS (Wellington Laboratories, Guelph, Canada), before instrument analysis. PCDD/Fs and PCBs analyses were performed using high-resolution gas chromatography (HRGC; Agilent 6890 high resolution gas chromatograph; Agilent Technologies, Santa Clara, CA, USA) and high resolution mass spectrometry (Autospec Ultima high resolution mass spectrometer; Waters, Milford, MA, USA). The GC oven program for PCDD/F analysis was as follows: held at $160^{\circ} \mathrm{C}$ for $2 \mathrm{~min}$, increased at a rate of $5^{\circ} \mathrm{C} \mathrm{min}^{-1}$ to $220^{\circ} \mathrm{C}$ (held $16 \mathrm{~min}$ ), increased at a rate of $4{ }^{\circ} \mathrm{C} \mathrm{min}^{-1}$ to $235^{\circ} \mathrm{C}$ (held $7 \mathrm{~min}$ ), and increased at a rate of $5^{\circ} \mathrm{C} \mathrm{min}^{-1}$ to $330^{\circ} \mathrm{C}$ (held $1 \mathrm{~min}$ ). The GC oven program for PCB analysis was as follows: held at $80^{\circ} \mathrm{C}$ for $2 \mathrm{~min}$, increased at a rate of $15^{\circ} \mathrm{C} \mathrm{min}{ }^{-1}$ to $150^{\circ} \mathrm{C}$, increased at a rate of $2.5^{\circ} \mathrm{C} \mathrm{min}^{-1}$ to $270^{\circ} \mathrm{C}$ (held $3 \mathrm{~min}$ ), and increased at a rate of $15^{\circ} \mathrm{C} \mathrm{min}{ }^{-1}$ to $330^{\circ} \mathrm{C}$ (held $1 \mathrm{~min}$ ). Simultaneously, non-2,3,7,8-substituted gas-phase PCDD/Fs in samples were determined based on retention times and the order of peaks after Fishman et al (Fishman et al., 2011). A total of 132 PCDD/Fs were detected, including 17 different 2,3,7,8-substituted PCDD/Fs in the gas phase (Supporting Information, Table S1).

To identify the sinks of PCDD/Fs and PCBs in the flue gas, the Hybrid Single-Particle Lagrangian-Integrated Trajectory (HYSPLIT) model (established by National Oceanic and Atmospheric Administration) was used to simulate forward trajectories of emission sources, know to release PCDD/Fs and PCBs (Han et al., 2016).

\section{Quality Assurance and Quality Control}

Validation of our analysis method for PCDD/Fs was assessed using measures for repeatability, reproducibility, accuracy, and sensitivity. The repeatability and reproducibility of instruments and our method were evaluated using standard deviations of replicate analyses. The difference between observed and theoretical peak areas of PCDD/Fs was used as a measure of accuracy. One laboratory blank was analyzed in each batch of the samples. Sensitivity was estimated using both the limit of detection (LOD) and limit of quantification (LOQ). The LODs of the PCDD/Fs and PCBs ranged from 0.07 to $2.65 \mathrm{pg} \mathrm{m}^{-3}$ and from 0.12 to
$3.49 \mathrm{pg} \mathrm{m}^{-3}$, respectively. The sample recoveries of $\mathrm{PCDD} / \mathrm{Fs}$ (PCBs) were between 42.9 (25.6\%) and 141\% (109\%), which meet the requirements for their trace analysis. The concentrations of $\mathrm{PCDD} / \mathrm{Fs}$ and $\mathrm{PCBs}$ with values below their LOD (less than 5\%) were assigned concentrations of half their LOD values. In this study, toxic equivalency values (TEQs) for the 17 different 2,3,7,8-substituted PCDD/Fs and 12 dl-PCBs were quantified using their respective World Health Organization toxic equivalency factors $\left(\mathrm{WHO}_{2005}-\right.$ TEF) (Pan et al., 2010).

\section{RESULTS AND DISCUSSION}

\section{Concentrations of 2,3,7,8-PCDD/Fs and PCBs in Flue Gases}

The specific contribution of PCDD/Fs and dl-PCBs to different particle fractions, phases, and condensed water in the flue gas samples is shown in Fig. 2.

The total concentrations of PCDD/Fs in the flue gas ranged from 0.75 to $15 \mathrm{ng} \mathrm{m}^{-3}$, with an average concentration of $6.5 \mathrm{ng} \mathrm{m}^{-3}$ (giving TEQ of $0.59 \mathrm{ng}$ TEQ $\mathrm{m}^{-3}$ ). Total concentrations of dl-PCBs in the flue gas were in the range of $0.18-28 \mathrm{ng} \mathrm{m}^{-3}$, with an average concentration of $11 \mathrm{ng} \mathrm{m}^{-3}$ (giving TEQ of $0.08 \mathrm{ng}$ TEQ $\mathrm{m}^{-3}$ ). Concentrations of indicator PCBs ranged from 66 to $1415 \mathrm{ng} \mathrm{m}^{-3}$, having a mean concentration that was 67 times that of dl-PCBs. Although $\mathrm{PCDD} / \mathrm{F}$ concentrations were lower than levels of dl-PCBs, the average TEQ of PCDD/Fs were 7.4 orders higher than dl-PCBs.

Total PCDD/Fs and dl-PCBs in the flue gas were presented, in decreasing order, within gas phases, particulate phases, and aqueous phases. The total concentrations of PCDD/Fs in gas phases were in the range of $0.53-7.1 \mathrm{ng} \mathrm{m}^{-3}$, with a mean concentration of $4.1 \mathrm{ng} \mathrm{m}^{-3}$. In particles, PCDD/Fs ranged from 0.14 to $8.1 \mathrm{ng} \mathrm{m}^{-3}$, with a mean concentration of $2.2 \mathrm{ng} \mathrm{m}^{-3}$. In contrast, dl-PCBs in gas phases were in the range of 4.4-28 $\mathrm{ng} \mathrm{m}^{-3}$, with a mean concentration of $11 \mathrm{ng} \mathrm{m}^{-3}$; while in the particulate phase, dl-PCBs ranged from 0.041 to $1.3 \mathrm{ng} \mathrm{m}^{-3}$, with a mean concentration of $0.33 \mathrm{ng} \mathrm{m}^{-3}$. Indicator PCBs in gas phases were in the range of 34-1403 $\mathrm{ng} \mathrm{m}^{-3}$, with a mean concentration of 608

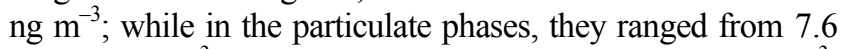
to $674 \mathrm{ng} \mathrm{m}^{-3}$, with a mean concentration of $147 \mathrm{ng} \mathrm{m}^{-3}$. Indicator PCBs in sample set $\mathrm{S} 1$ had highest concentrations in the particulate phase.

Total concentrations of $\mathrm{PCDD} / \mathrm{Fs}$ in condensed water samples were in the range of $0.94-16 \mathrm{ng} \mathrm{L}^{-1}$, with a mean concentration of $4.9 \pm 6.2 \mathrm{ng} \mathrm{L}^{-1}$ (giving TEQ of $0.40 \pm$ $0.36 \mathrm{ng}$ TEQ $\mathrm{L}^{-1}$ ). The dl-PCBs in condensed water samples ranged from 0.72 to $16 \mathrm{ng} \mathrm{L}^{-1}$, with a mean concentration of $5.4 \pm 6.7 \mathrm{ng} \mathrm{L}^{-1}$ (giving TEQ of $0.06 \pm 0.09 \mathrm{ng} \mathrm{TEQ} \mathrm{L}^{-1}$ ). The average TEQ of PCDD/Fs were 6.7 times higher than dl-PCBs. Indicator PCBs in condensed water samples ranged from 2.6 to $842 \mathrm{ng} \mathrm{L}^{-1}$, with a mean concentration of $289 \pm$ $347 \mathrm{ng} \mathrm{L}^{-1}$. Converting PCDD/F and PCB concentrations in condensed water into volume concentrations of the flue gas, yielded average levels of PCDD/Fs, PCBs and dl-PCBs that were $0.15 \pm 0.11 \mathrm{ng} \mathrm{m}^{-3}, 11 \pm 11 \mathrm{ng} \mathrm{m}^{-3}$, and $0.21 \pm$ $0.20 \mathrm{ng} \mathrm{m}^{-3}$, respectively. 

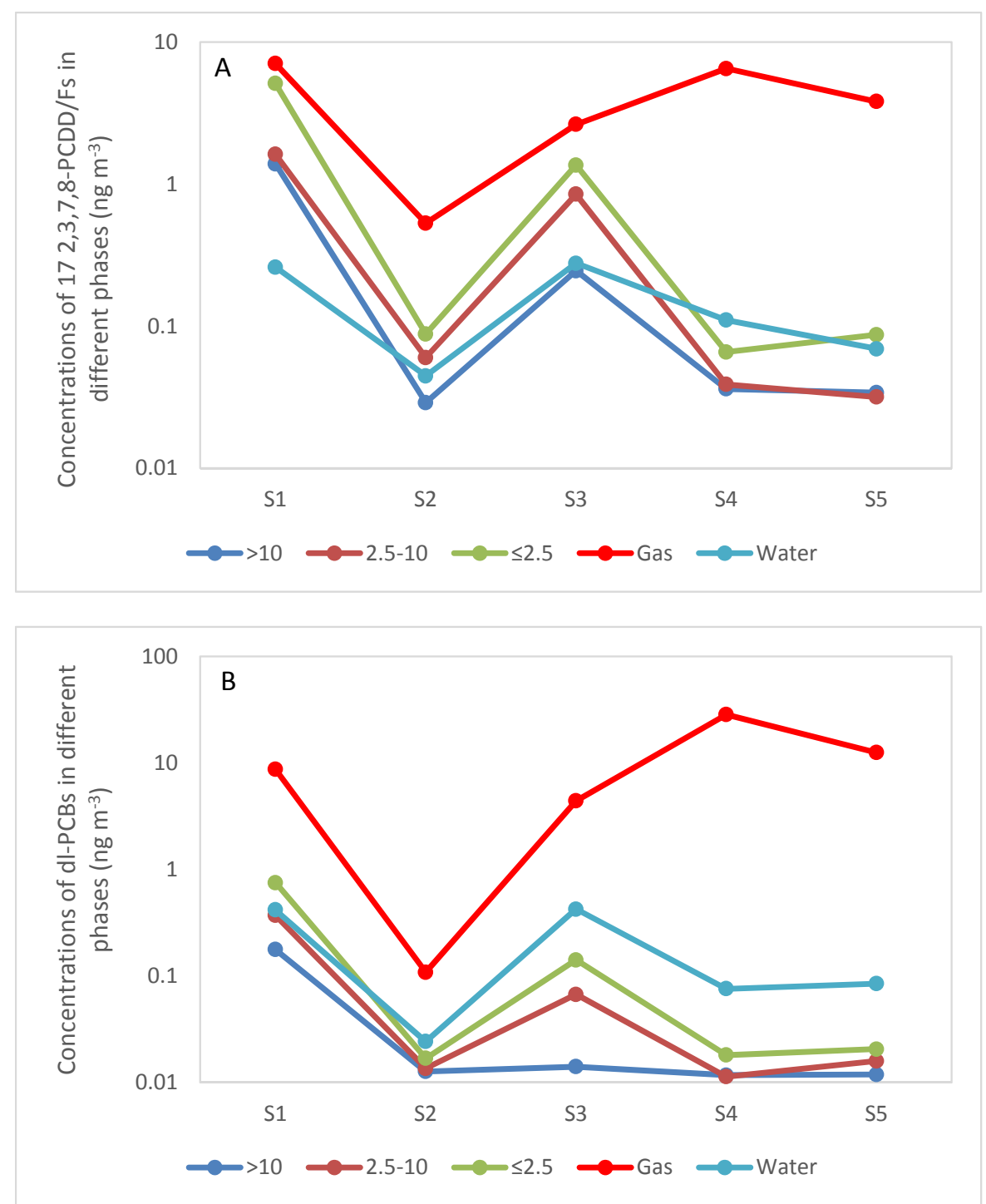

Fig. 2. Concentrations of PCDD/Fs (A) and dl-PCBs (B) in different phases of the flue gas.

\section{Gas-Particle-Water Partitioning of 2,3,7,8-PCDD/Fs and PCBS}

$\mathrm{PCDD} / \mathrm{Fs}$ and PCBs occurred in largest proportions in the gas phases, based on their whole gas-particle-water partitioning distribution characteristics. Concentration contributions of PCDD/Fs and dl-PCBs in different phases to the total $\mathrm{PCDD} / \mathrm{Fs}$ and $\mathrm{dl}-\mathrm{PCBs}$ in the flue gas are described in Figs. 3(A) and 3(B). In addition, the profiles of the sum total of 2,3,7,8-PCDD/Fs and PCBs, based on their chlorine atoms, are depicted in Figs. 3(C) and 3(D).

The average contribution of PCDD/Fs in gas, particle, and water fractions to the sum total of 17 different $2,3,7,8$ $\mathrm{PCDD} / \mathrm{Fs}$ in the flue gas were $71 \%, 26 \%$, and $3.2 \%$, respectively. Proportions of dl-PCBs in gas, particle, and water fractions to total dl-PCBs in the flue gas were $86 \%$, $8.4 \%$, and $5.4 \%$, respectively. PCDD/Fs and dl-PCBs were mainly presented in the gas phases in all sample sets, except for sample set S1. PCDD/Fs in gas phases in S1 accounted for $46 \%$, which was slightly smaller than for particulate phases $(53 \%)$. Meanwhile, $\mathrm{PCDD} / \mathrm{Fs}$ in the gas phases in S2 were 3 times that in the particulate phases. It is possible that updating the bag filter at MSWI A, improved dust removal efficiency, specifically reducing the emission of PCDD/Fs in fine particles, post-S1 sampling. Likewise, $\mathrm{PCDD} / \mathrm{Fs}$ and dl-PCBs obviously decreased in the condensed water fraction of S2 compared with S1. PCDD/Fs and dl$\mathrm{PCBs}$ in gas and particulate phases from sample sets $\mathrm{S} 3$, $\mathrm{S} 4$, and S5 were similar.

Congener profiles of 2,3,7,8-PCDD/Fs and PCBs were also investigated to evaluate gas-particle-water partitioning of $\mathrm{PCDD} / \mathrm{Fs}$ and $\mathrm{PCBs}$ in the flue gas. As shown in Figs. 3(C) and 3(D), less chlorinated PCDD/Fs (TCDD/Fs and $\mathrm{PeCDD} / \mathrm{Fs}$ ) were more common in gas phases (above $60 \%$ ), while higher chlorinated ones ( $\mathrm{HxCDD} / \mathrm{Fs}, \mathrm{HpCDD} / \mathrm{Fs}$, and OCDD/Fs) occurred equally in both gas and particulate phases. All chlorinated PCBs, including TrCBs, TeCBs, $\mathrm{PeCBs}, \mathrm{HxCBs}$, and $\mathrm{HpCBs}$ mainly occurred in the gas phases, accounting for more than $70 \%$. However, PCDD/Fs and PCBs in the water fraction were below $10 \%$.

Clearly, gas phase PCDD/Fs and dl-PCBs released to the 

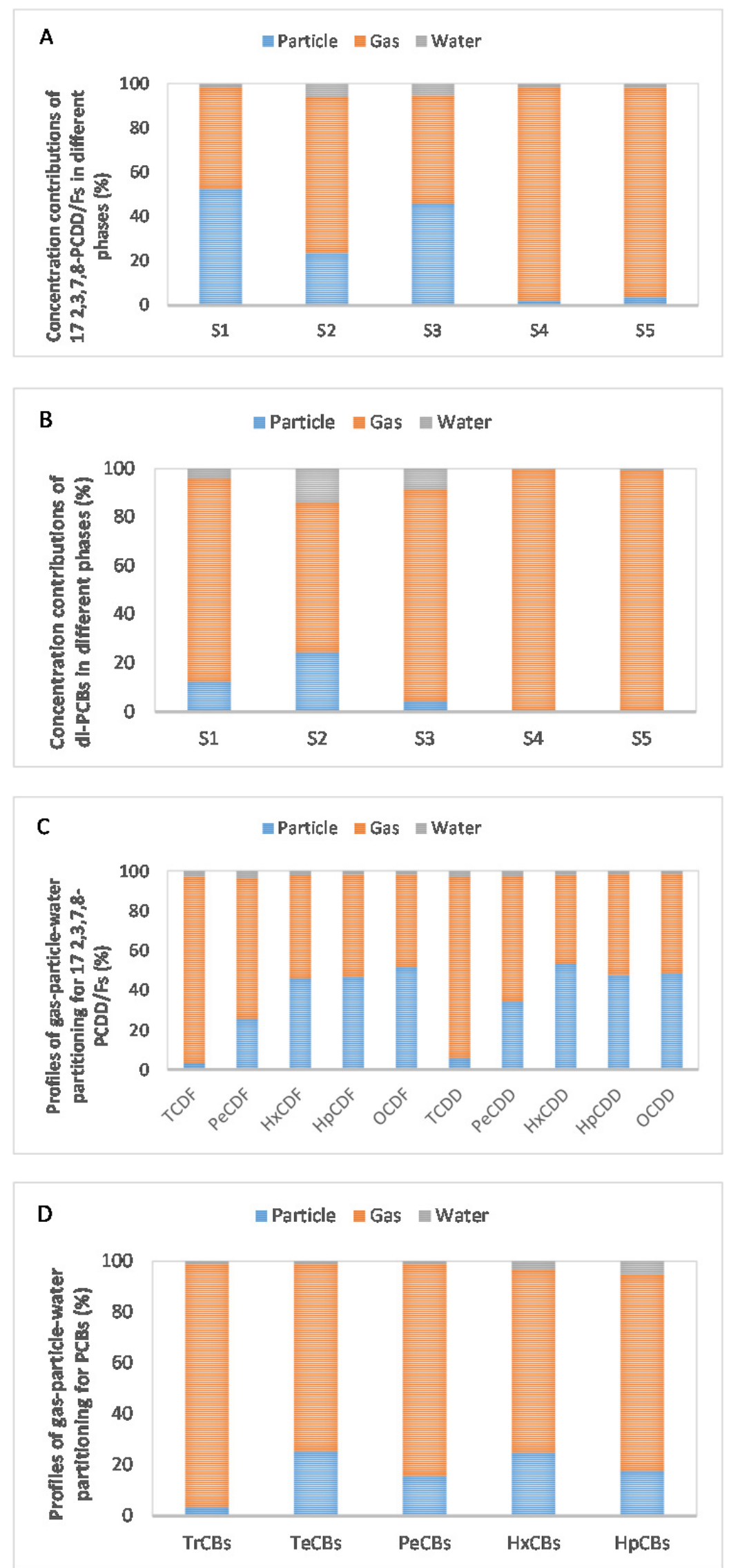

Fig. 3. Concentration contributions of $\mathrm{PCDD} / \mathrm{Fs}(\mathrm{A})$ and dl-PCBs (B) to different phases and profiles of gas-particle-water partitioning for PCDD/F (C) and PCB (D) congeners. 
ambient air are more easily photodegraded than particulate phases, contributing to a greater extent to haze formation (Chao et al., 2003). However, it is clearly necessary to investigate $\mathrm{PCDD} / \mathrm{Fs}$ and dl-PCBs in all phases to assess their environmental and health impacts.

\section{Particle Size Distributions of 2,3,7,8-PCDD/Fs and PCBs}

Concentrations of $\mathrm{PCDD} / \mathrm{Fs}$ and dl-PCBs in particulate matter having diameters less than $10 \mu \mathrm{m}\left(\mathrm{PM}_{10}\right)$ ranged from 0.10 to $6.7 \mathrm{ng} \mathrm{m}^{-3}$ (with a median of $0.15 \mathrm{ng} \mathrm{m}^{-3}$ ) and from 0.03 to $1.1 \mathrm{ng} \mathrm{m}^{-3}$ (with a median of $0.04 \mathrm{ng} \mathrm{m}^{-3}$ ), respectively. This accounts for more than $81 \%$ and $79 \%$ of the total particulate matter. In the $\mathrm{PM}_{2.5}$ fraction, the $\mathrm{PCDD} / \mathrm{F}$ level was in a range of $0.07-5.1 \mathrm{ng} \mathrm{m}^{-3}$, and was $0.02-$ $0.75 \mathrm{ng} \mathrm{m}^{-3}$ for dl-PCBs. For particles larger than $\mathrm{PM}_{10}$, the mean and median concentrations of PCDD/Fs (dl-PCBs) were $0.35(0.05)$ and $0.04(0.01) \mathrm{ng} \mathrm{m}^{-3}$, respectively. Indicator PCBs in particles with different diameters showed no significant variation. Levels of indicator PCBs in particle fractions larger than $\mathrm{PM}_{10}, \mathrm{PM}_{2.5-10}$, and $\mathrm{PM}_{2.5}$ were 50, 46, and $51 \mathrm{ng} \mathrm{m}^{-3}$, respectively. Clearly, more PCDD/Fs and dl-PCBs were present in smaller sized particles. The $\mathrm{PM}_{2.5}$ fraction made the highest contribution of more than $54 \%$ (49\%) of PCDD/Fs (dl-PCBs) to the particulate phase. The $\mathrm{PM}_{2.5} / \mathrm{PM}_{10}$ ratios in this study were $0.67 \pm 0.07$ and $0.62 \pm$ 0.06 for PCDD/Fs and dl-PCBs, respectively. Such high levels of PCDD/Fs and dl-PCBs can be attributed to primary emissions from the MSWIs.

Particle size distributions of PCDD/F and dl-PCB concentrations and TEQs in samples collected in this study are shown in Fig. 4. The TEQ of PCDD/Fs and dl-PCBs in different particle sizes shows a similar trend in all sample sets, increasing gradually with decreasing size of particles. In $\mathrm{PM}_{2.5}$, the mean concentrations of PCDD/Fs and dl-PCBs were $0.10 \pm 0.14 \mathrm{ng}$ TEQ $\mathrm{m}^{-3}$ and $0.005 \pm 0.008 \mathrm{ng}^{\mathrm{T}} \pm \mathrm{EQ} \mathrm{m}^{-3}$, respectively. For $\mathrm{PM}_{2.5-10}$, the $\mathrm{PCDD} / \mathrm{F}$ mean concentration

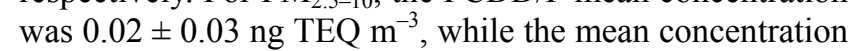
of dl-PCBs was $0.002 \pm 0.003 \mathrm{ng}$ TEQ $\mathrm{m}^{-3}$. In $\mathrm{PM}_{10}$, the mean concentrations of PCDD/Fs and dl-PCBs were $0.13 \pm$ $0.17 \mathrm{ng}$ TEQ $\mathrm{m}^{-3}$ and $0.006 \pm 0.01 \mathrm{ng}^{\mathrm{T}} \mathrm{TEQ} \mathrm{m}^{-3}$. For particles larger than $\mathrm{PM}_{10}, \mathrm{PCDD} / \mathrm{F}$ and dl-PCB mean concentrations were $0.01 \pm 0.02 \mathrm{ng}$ TEQ $\mathrm{m}^{-3}$ and $0.0004 \pm 0.0006 \mathrm{ng}$ TEQ $\mathrm{m}^{-3}$. Thus, the TEQ contributions of PCDD/Fs were dozen times higher than dl-PCBs.

Although a number of studies have investigated the concentrations of various sized $\mathrm{PCDD} / \mathrm{Fs}$ in the atmosphere (Oha et al., 2002; Sharma and Maloo, 2005; Barmpadimos et al., 2012; Lee et al., 2016), few have described the gasparticle partitioning of dl-PCBs. This is relevant because the processes of transportation and deposition of particles are determined by particle size (Chao et al., 2003). To compare our results with other studies, the concentrations of PCDD/Fs and dl-PCBs in particles of various diameters in the flue gas are compared with values for particulate matter in the atmosphere. Generally, other studies found that substance loading on particles increases, with decreasing particle size. The results obtained in our study are consistent with such studies (Zhang et al., 2015), since higher levels of PCDD/Fs and dl-PCBs were detected in smaller particle sizes. Lee et al. (2016) reported much higher concentrations of $\mathrm{PM}_{2.5}$ and PCDD/Fs in the ambient air of Xiaogang area, in southern Taiwan, with heavy industrial activities than local urban and rural areas. This suggests that flue gases emitted from MSWIs are an important emission source of PCDD/Fs and dl-PCBs to the atmosphere.

\section{Profiles of 2,3,7,8-Chlorinated and Non-2,3,7,8- Chlorinated PCDD/Fs}

Both PCDD/Fs and dl-PCBs have potential for long-range atmospheric transport. Generally, the toxic effects caused by $\mathrm{PCDD} / \mathrm{Fs}$ were higher than for dl-PCBs, especially for gasphase PCDD/Fs (Fig. 4). Most studies focused on the toxicities of 17 2,3,7,8-substituted PCDD/F congeners (Xu et al., 2013; Cai et al., 2016), while few studies have looked at non-2,3,7,8-chlorinated PCDD/Fs due to lack of data of toxicity.

Fishman et al. (2011) evaluated $136 \mathrm{PCDD} / \mathrm{Fs}$ in their study. Based on their results, a high number of gas-phase $\mathrm{PCDD} / \mathrm{F}$ congeners were measured in this study (Table S1). Not all these PCDD/Fs were detected in other phases of our sampling sets. Total concentrations of 132 gas-phase $\mathrm{PCDD} / \mathrm{Fs}$ in sample sets S1, S2, S3, S4, and S5 were 16.2, $1.01,10.2,127$, and $107 \mathrm{ng} \mathrm{m}^{-3}$, respectively. Similarly, concentrations of 17 different 2,3,7,8-substituted PCDD/Fs in sample sets S1, S2, S3, S4, and S5 were 7.06, 0.53, 2.63, 6.50 , and $3.81 \mathrm{ng} \mathrm{m}^{-3}$, respectively. This indicates that levels of non-2,3,7,8-chlorinated PCDD/Fs were much higher than 2,3,7,8-chlorinated PCDD/Fs. The homologue distributions of gas-phase non-2,3,7,8-chlorinated PCDD/Fs in our samples are described using box plots in Fig. 5.

Low-chlorinated PCDD/Fs accounted for higher proportions in samples than highly chlorinated ones; this can be correlated with the number of congeners. TCDF contributed $46 \%$ to total PCDD/F concentrations, of which non-2,3,7,8-chlorinated PCDD/Fs were critical components (Fig. 5(A)). Likewise, PeCDF and TCDD concentrations in total $\mathrm{PCDD} / \mathrm{F}$ concentrations were high, but not in the 2,3,7,8-chlorinated PCDD/F component. TCDF compounds, 1,3,4,6-TCDF, 1,2,4,6-TCDF, 1,3,4,7-TCDF, 1,3,7,8-TCDF, and 1,2,4,7-TCDF were eluted simultaneously, contributing most $(20.7 \%)$ to samples, followed by compounds $1,3,6,9$ TCDF and 1,2,3,7-TCDF (11.1\%), and finally 2,3,6,7-TCDF and 3,4,6,7-TCDF (9.30\%). In the case of PeCDFs, 1,2,3,6,8PeCDF/1,3,4,7,8-PeCDF/1,2,4,7,8-PeCDF was the most abundant homologue, accounting for $26.5 \%$, followed by 2,3,4,6,7-PeCDF/1,2,3,6,9-PeCDF (12.9\%). In the case of TCDD, 1,3,7,9-TCDD and 1,3,6,8-TCDD contributed 23.1\% and $15.4 \%$ to total TCDD concentrations, respectively. To understand the relationships between 2,3,7,8-substituted $\mathrm{PCDD} / \mathrm{Fs}$ and non-2,3,7,8-chlorinated compounds in our samples, the ratios of non-2,3,7,8-chlorinated PCDD/Fs and 2,3,7,8-chlorinated PCDD/Fs, except for OCDDs and OCDFs, are shown in Fig. 5(B). These ratios clearly show higher non-2,3,7,8-chlorinated PCDD/F levels than 2,3,7,8chlorinated PCDD/Fs, especially for TCDDs, TCDFs, and PeCDFs.

According to the calculations for bond dissociation energy, 2-C and 3-C bonds in the $\mathrm{PCDD} / \mathrm{F}$ structures are 

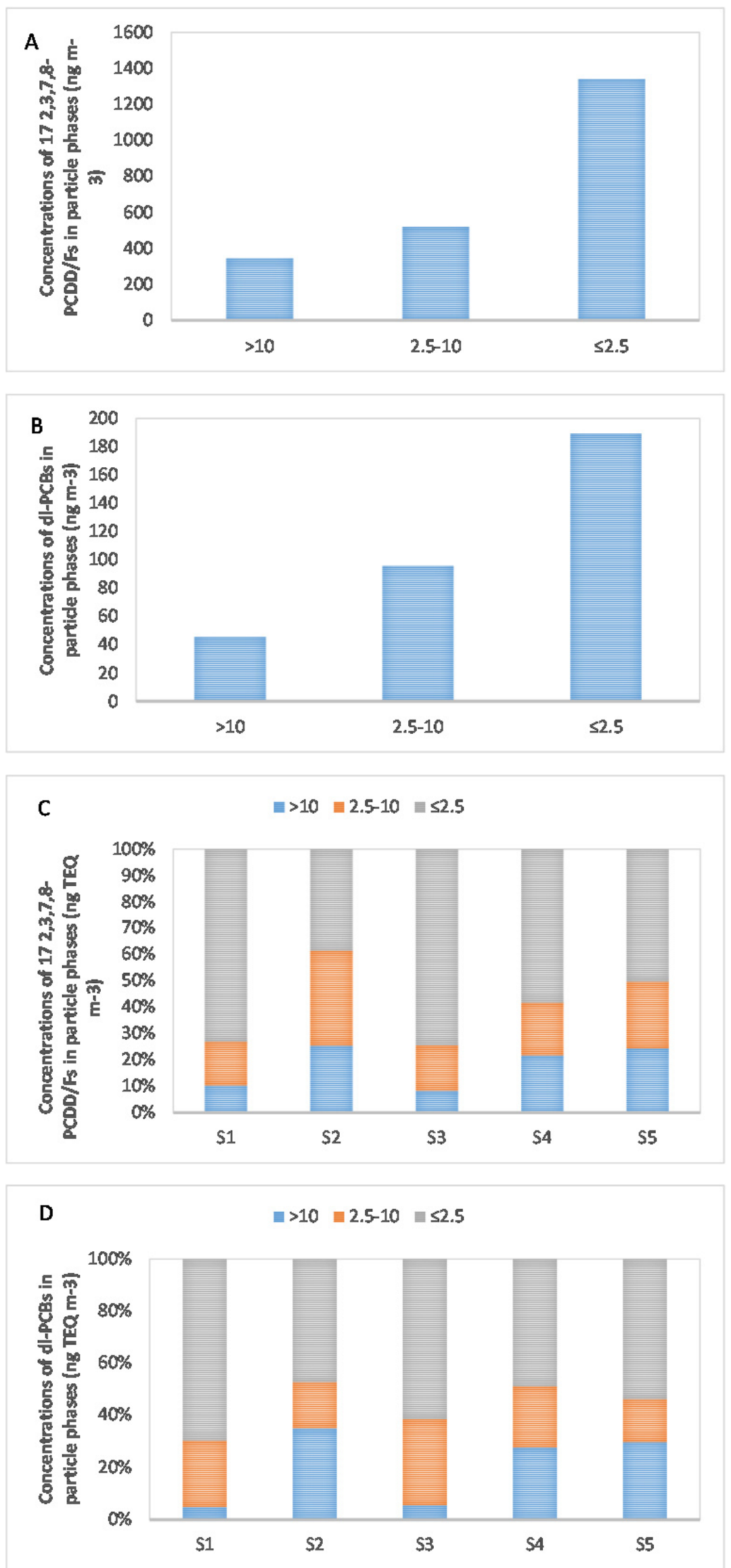

Fig. 4. Concentrations and TEQ of PCDD/Fs (A and C) and dl-PCBs (B and D) in different particle fractions. 

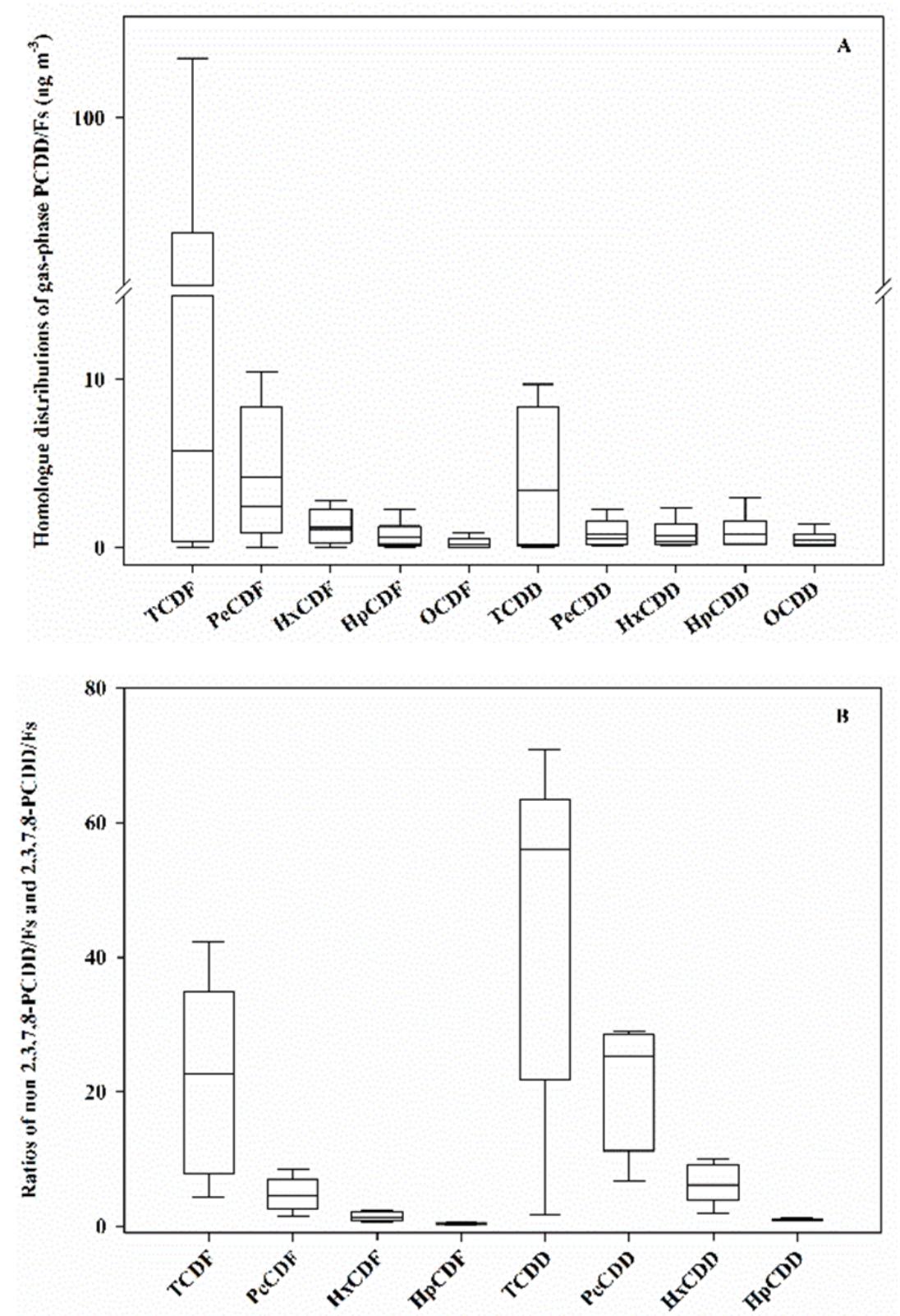

Fig. 5. Total concentrations of non-2,3,7,8-chlorinated versus 2,3,7,8-chlorinated PCDD/Fs in gas-phase samples.

more easily chlorinated (Han et al., 2015). This suggests that the non-2,3,7,8-chlorinated PCDD/F compounds described above could be easily chlorinated to $2-\mathrm{C}-\mathrm{Cl}$ and $3-\mathrm{C}-\mathrm{Cl}$ forms. Non-2,3,7,8-chlorinated PCDD/Fs may be converted to $2,3,7,8$-chlorinated $\mathrm{PCDD} / \mathrm{Fs}$ by microorganisms over time, given that they are more stable in the environment. Therefore, greater attention should be paid to non-2,3,7,8chlorinated $\mathrm{PCDD} / \mathrm{Fs}$, given their high levels in the atmosphere, and their potential health risks to humans on transformation. Furthermore, non-2,3,7,8-chlorinated $\mathrm{PCDD} / \mathrm{Fs}$ could provide a theoretical model for reduction of emissions of 2,3,7,8-chlorinated PCDD/Fs.

Given that levels of PCDD/Fs are close to the LOD in the particulate phase, non-2,3,7,8-chlorinated PCDD/Fs were only detected in one particulate sample $\left(\mathrm{PM}_{2.5}\right.$ in $\left.\mathrm{S} 1\right)$. The total concentration of non-2,3,7,8-chlorinated PCDD/Fs in fine particles was $11.2 \mathrm{ng} \mathrm{m}^{-3}$, while 2,3,7,8-chlorinated species had concentrations of $5.11 \mathrm{ng} \mathrm{m}^{-3}$. This trend was similar for compounds found in the gas phase, where levels of non-2,3,7,8-chlorinated PCDD/Fs were much higher than 2,3,7,8-chlorinated PCDD/Fs, especially for TCDDs, TCDFs, and PeCDDs, having ratios of 140, 45.4, and 26.7, respectively.

\section{Relationship between Haze-Fog and PCDD/F and dl-PCB Levels in Flue Gases}

Since 2013, serious haze-fog events caused by aerosols, especially $\mathrm{PM}_{2.5}$, have occurred frequently in China. These events are related to high emissions of atmospheric contaminants. Such events play a critical role in environmental and human health (Qiao et al., 2015; Fu and Chen, 2017). Haze-fog episodes form through complex 


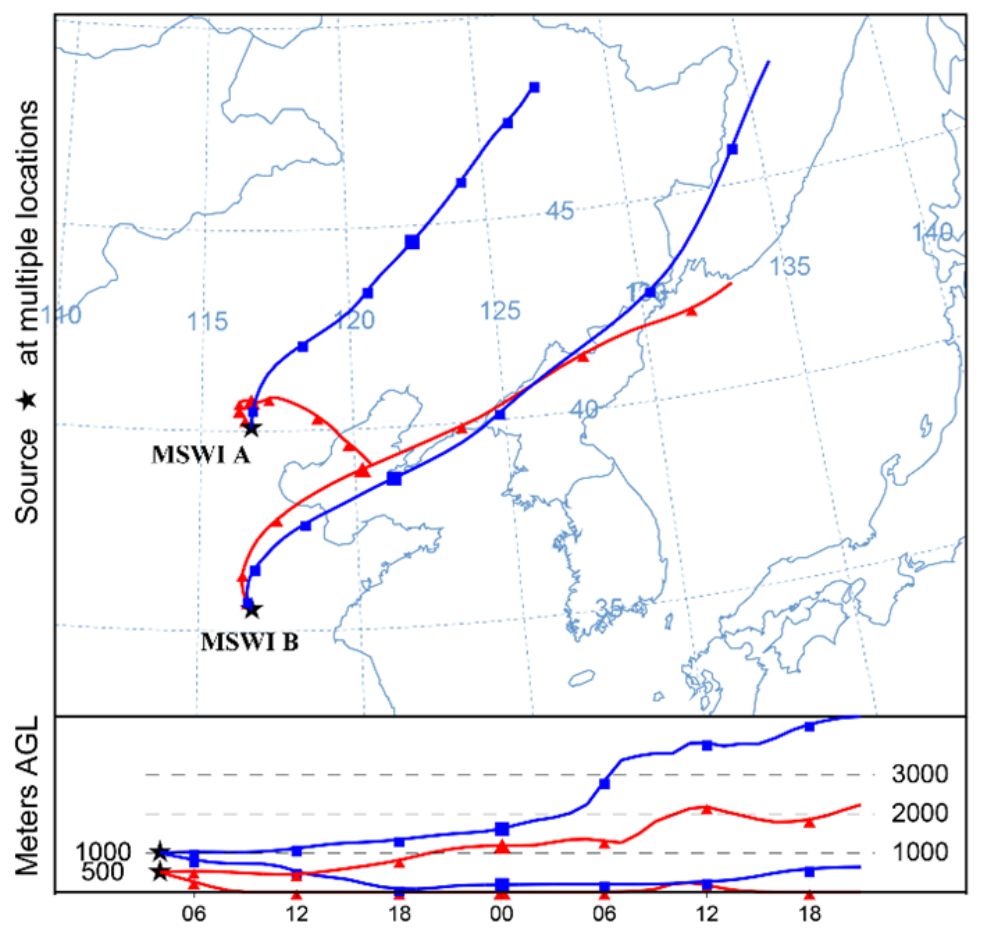

Fig. 6. Forward trajectories of PCDD/Fs and dl-PCBs emitted from two municipal solid waste incinerators (MSWIs A and B).

atmospheric reactions. In particular, water content in the atmosphere is an important factor contributing to the formation of haze-fog. In addition, emission sources, secondary aerosol formation, regional particulate transport, and adverse meteorological conditions contribute to serious haze-fog events (Fu and $\mathrm{Chen,} \mathrm{2017).} \mathrm{Some} \mathrm{studies} \mathrm{have}$ shown that MSWIs are an important emission source of $\mathrm{PM}_{2.5}$ (Yan et al., 2016), given that the fine particles they release to the atmosphere are slow to decompose (Chao et al., 2003).

We simulated the forward trajectories of PCDD/Fs and dl-PCBs emitted from the two MSWIs of this study (Fig. 6). Flue gas at two different heights $(500 \mathrm{~m}$ and $1000 \mathrm{~m})$ was simulated using ground meteorological data for $120 \mathrm{~h}(5 \mathrm{~d})$ in the HYSPLIT model. Our simulations showed that air masses with high pollution levels move towards northeastern regions. Although transport paths of PCDD/Fs and dl-PCBs at $500 \mathrm{~m}$ and $1000 \mathrm{~m}$ were different, their forward trajectories all dissipated over the heavily polluted northeastern plain. This pollution clearly contributes to the formation of hazefog episodes. In this case, PCDD/Fs and dl-PCBs move away from their emission sources, suggesting that MSWIs should be located at safe distances from high-density population areas to prevent adverse effects on environment and human health.

\section{CONCLUSIONS}

The concentrations and gas-particle-water partitioning of $\mathrm{PCDD} / \mathrm{Fs}$ and PCBs were investigated in MSWI flue gases. (1) Total PCDD/Fs and dl-PCBs in the flue gas were presented, in decreasing order, within gas phases, particulate phases, and aqueous phases. Total concentrations of
$\mathrm{PCDD} / \mathrm{Fs}$ in the flue gas ranged from 0.75 to $15 \mathrm{ng} \mathrm{m}^{-3}$ and dl-PCBs (indicator PCBs) in the flue gas were in the range of $0.18-28(66-1415) \mathrm{ng} \mathrm{m}^{-3}$. (2) Average percentages of $\mathrm{PCDD} / \mathrm{Fs}$ in gas, particle, and water components to the sum total of $172,3,7,8-\mathrm{PCDD} / \mathrm{Fs}$ in the flue gas were $71 \%, 26 \%$, and $3.2 \%$, respectively; while dl-PCBs in gas, particles, and water components to total dl-PCBs in the flue gas were $86 \%$, $8.4 \%$, and $5.4 \%$, respectively. (3) $\mathrm{PCDD} / \mathrm{Fs}$ and $\mathrm{dl}-\mathrm{PCBs}$ increased with decreasing particle size and were highest in $\mathrm{PM}_{2.5}$, contributing more than 54\% (49\%) of PCDD/Fs (dlPCBs) to the particulate phase. (4) Concentrations of non2,3,7,8-chlorinated PCDD/Fs were much higher than 2,3,7,8-chlorinated PCDD/Fs and low-chlorinated PCDD/Fs accounted for higher proportions than highly chlorinated $\mathrm{PCDD} / \mathrm{Fs}$.

\section{CONFLICTS OF INTEREST}

None declared.

\section{ACKNOWLEDGEMENTS}

This work was supported by the State Key Project of the Research and Development Plan [grant number 2016YFC0202500]; the National Natural Science Foundation of China [grant numbers 21477150, 21677169 and 21577148 ].

\section{SUPPLEMENTARY MATERIAL}

Concentrations of 132 gas-phase $\mathrm{PCDD} / \mathrm{Fs}$ in sample sets S1-S5 are described in Table S1 in the Supporting Information. Supplementary data associated with this article 
can be found in the online version at http://www.aaqr.org.

\section{REFERENCES}

Ba, T., Zheng, M., Zhang, B., Liu, W., Su, G. and Xiao, K. (2009). Estimation and characterization of PCDD/Fs and dioxin-like PCB emission from secondary zinc and lead metallurgies in China. J. Environ. Monit. 11: 867-872.

Baek, S.Y., Choi, S.D., Park, H., Kang, J.H. and Chang, Y.S. (2010). Spatial and seasonal distribution of polychlorinated biphenyls (PCBs) in the vicinity of an iron and steel making plant. Environ. Sci. Technol. 44: 3035-3040.

Barmpadimos, I., Keller, J., Oderbolz, D., Hueglin, C. and Prévôt, A.S.H. (2012). One decade of parallel $\mathrm{PM}_{10}$ and $\mathrm{PM}_{2.5}$ measurements in Europe: trends and variability. Atmos. Chem. Phys. 12: 3189-3203.

Cai, M., Hong, Q., Sun, J., Sundqvist, K., Wiberg, K., Chen, K., Wang, Y., Qiu, C. and Huang, S. (2016). Concentrations, distribution and sources of polychlorinated dibenzo- $p$-dioxins and dibenzofurans and dioxin-like polychlorinated biphenyls in coastal sediments from Xiamen, China. Mar. Chem. 185: 74-81.

Cetin, B., Ozturk, F., Keles, M. and Yurdakul, S. (2017). PAHs and PCBs in an Eastern Mediterranean megacity, Istanbul: Their spatial and temporal distributions, air-soil exchange and toxicological effects. Environ. Pollut. 220: 1322-1332.

Chang, H.J., Lin, T.F., Whang, L.M. and Wu, Y.J. (2016). Congener profiles of polychlorinated dibenzo- $p$-dioxins and polychlorinated dibenzofurans (PCDD/Fs) in sediment, water, and fish at a soil contamination site in Taiwan. $J$. Environ. Sci. Health. Part A Toxic/Hazard. Subst. Environ. Eng. 51: 251-261.

Chao, M.R., Hu, C.W., Ma, H.W., Chang-Chien, G.P., Lee, W.J., Chang, L.W. and Wu, K.Y. (2003). Size distribution of particle-bound polychlorinated dibenzo- $p$-dioxins and dibenzofurans in the ambient air of a municipal incinerator. Atmos. Environ. 37: 4945-4954.

Chi, K.H., Hung, N.T., Lin, C.Y., Wang, S.H., Ou-Yang, C.F., Lee, C.T. and Lin, N.H. (2016). Evaluation of atmospheric PCDD/Fs at two high-altitude stations in Vietnam and Taiwan during Southeast Asia biomass burning. Aerosol Air Qual. Res. 16: 2706-2715.

Chrysikou, L.P. and Samara, C.A. (2009). Seasonal variation of the size distribution of urban particulate matter and associated organic pollutants in the ambient air. Atmos. Environ. 43: 4557-4569.

Chrysikou, L.P., Gemenetzis, P.G. and Samara, C.A. (2009). Wintertime size distribution of polycyclic aromatic hydrocarbons (PAHs), polychlorinated biphenyls (PCBs) and organochlorine pesticides (OCPs) in the urban environment: Street- vs rooftop-level measurements. Atmos. Environ. 43: 290-300.

Du, B., Zheng, M., Tian, H., Liu, A., Huang, Y., Li, L., Ba, T., Li, N., Ren, Y., Li, Y., Dong, S. and Su, G. (2010). Occurrence and characteristics of polybrominated dibenzo$p$-dioxins and dibenzofurans in stack gas emissions from industrial thermal processes. Chemosphere 80: 1227-1233.

Du, Y., Chen, T., Lu, S., Yan, J., Li, X., Cen, K., Nakamura,
M. and Handa, H. (2011). Comparative analysis of $\mathrm{PCDD} / \mathrm{Fs}$ in soil around waste incineration plants in China using CALUX bioassay and HRGC/HRMS. J. Hazard. Mater. 192: 1729-1738.

Fishman, V.N., Martin, G.D. and Wilken, M. (2011). Retention time profiling of all 136 tetra- through octachlorinated dibenzo- $p$-dioxins and dibenzofurans on a variety of Si-Arylene gas chromatographic stationary phases. Chemosphere 84: 913-922.

$\mathrm{Fu}, \mathrm{H}$. and Chen, J. (2017). Formation, features and controlling strategies of severe haze-fog pollutions in China. Sci. Total Environ. 578: 121-138.

Guo, C.J., Wang, M.S., Lin, S.L., Mi, H.H., Wang, L.C. and Chang-Chien, G.P. (2014). Emissions of PCDD/Fs and PCBs during the cold start-up of municipal solid waste incinerators. Aerosol Air Qual. Res. 14: 1593-1604.

Hakk, H., Larsen, G. and Feil, V. (2001). Tissue distribution, excretion, and metabolism of 1,2,7,8-tetrachlorodibenzop-dioxin in the rat. Chemosphere 42: 975-983.

Han, Y., Liu, W., Pan, W., Wang, P., Tian, Z., Zhao, Y., Wang, M., Chen, X., Liao, X. and Zheng, M. (2015). Formation pathways of mono- to octa-chlorinated dibenzo$p$-dioxins and dibenzofurans in main organochemical industries. Environ. Sci. Technol. 49: 10945-10950.

Han, Y., Xie, H., Liu, W., Li, H., Wang, M., Chen, X., Liao, X. and Yan, N. (2016a). Assessment of pollution of potentially harmful elements in soils surrounding a municipal solid waste incinerator, China. Front. Environ. Sci. Eng. 10: 1-7.

Han, Y., Liu, W., Hansen, H. C., Chen, X., Liao, X., Li, H., Wang, M. and Yan, N. (2016b). Influence of long-range atmospheric transportation (LRAT) on mono-to octachlorinated PCDD/Fs levels and distributions in soil around Qinghai Lake, China. Chemosphere 156: 143149.

Hanioka, N., Jinno, H., Toyo'oka, T. and Ando, M. (1994). The effect of 1,2,3,4-tetrachlorodibenzo-p-dioxin on drug-metabolizing enzymes in the rat liver. Chemosphere 29: 2477-2491.

Hu, J., Zheng, M., Liu, W., Li, C., Nie, Z., Liu, G., Xiao, K. and Dong, S. (2013). Occupational exposure to polychlorinated dibenzo- $p$-dioxins and dibenzofurans, dioxin-like polychlorinated biphenyls, and polychlorinated naphthalenes in workplaces of secondary nonferrous metallurgical facilities in China. Environ. Sci. Technol. 47: 7773-7779.

Kaupp, H. and McLachlan, M.S. (2000). Distribution of polychlorinated dibenzo- $P$-dioxins and dibenzofurans (PCDD/Fs) and polycyclic aromatic hydrocarbons (PAHs) within the full size range of atmospheric particles. Atmos. Environ. 34: 73-83.

Kurogawa, Y., Takahiko, M., Matayoshi, N., Satoshi, T. and Kazumi, F. (1998). Distribution of PCDD/Fs in various sizes of airborne particles. Chemosphere 37: 2161-2171.

Lee, K.L., Lee, W.J., Mwangi, J.K., Wang, L.C., Gao, X. and Chang-Chien, G.P. (2016). Atmospheric $\mathrm{PM}_{2.5}$ and depositions of polychlorinated dibenzo- $p$-dioxins and dibenzofurans in Kaohsiung area, Southern Taiwan. Aerosol Air Qual. Res. 16: 1775-1791. 
Li, X., Yan, M., Yang, J., Chen, T., Lu, S. and Yan, J. (2012). PCDD/Fs in soil around a hospital waste incinerator: Comparison after three years of operation. $J$. Environ. Sci. 24: 699-703.

Li, Y., Jiang, G., Wang, Y., Cai, Z. and Zhang, Q. (2008). Concentrations, profiles and gas-particle partitioning of polychlorinated dibenzo- $p$-dioxins and dibenzofurans in the ambient air of Beijing, China. Atmos. Environ. 42: 2037-2047.

Li, Y., Zhan, M., Chen, T., Zhang, J., Li, X., Yan, J. and Buekens, A. (2016). Formation, reduction and emission behaviors of CBzs and PCDD/Fs from cement plants. Aerosol Air Qual. Res. 16: 1942-1953.

Meng, B., Ma, W.L., Liu, L.Y., Zhu, N.Z., Song, W.W., Lo, C.Y., Li, J., Kannan, K. and Li, Y.F. (2016). PCDD/Fs in soil and air and their possible sources in the vicinity of municipal solid waste incinerators in northeastern China. Atmos. Pollut. Res. 7: 355-362.

Oha, J.E., Changa, Y.S., Kima, E.J. and Lee, D.W. (2002). Distribution of polychlorinated dibenzo- $p$-dioxins and dibenzofurans (PCDD/Fs) in different sizes of airborne particles. Atmos. Environ. 36: 5109-5117.

Pan, J., Yang, Y., Geng, C., Yeung, L.W., Cao, X. and Dai, T. (2010). Polychlorinated biphenyls, polychlorinated dibenzo- $p$-dioxins and dibenzofurans in marine and lacustrine sediments from the Shandong Peninsula, China. J. Hazard. Mater. 176: 274-279.

Petroske, E., Huwe, J.K., Feil, V.J. and Larsen, G.L. (1997). Identification of nih-shifted metabolites of 1,3,7,8-tetrachlorodibenzo- $p$-dioxin in the rat by $\mathrm{nmr}$ comparison with synthesized isomers. Chemosphere 34: $1549-1555$.

Qiao, T., Zhao, M., Xiu, G. and Yu, J. (2015). Seasonal variations of water soluble composition (WSOC, Hulis and WSIIs) in $\mathrm{PM}_{1}$ and its implications on haze pollution in urban Shanghai, China. Atmos. Environ. 123: 306-314.

Sharma, M. and Maloo, S. (2005). Assessment of ambient air PM and PM and characterization of PM in the city of Kanpur, India. Atmos. Environ. 39: 6015-6026.

Suryani, R.C., Lee, W.J., Mutiara, M.P.E., Mwangi, J.K., Wang, L.C., Lin, N.H. and Chang-Chien, G.P. (2015). Atmospheric deposition of polychlorinated dibenzo- $p$ dioxins and dibenzofurans at coastal and high mountain areas in Taiwan. Aerosol Air Qual. Res. 15: 1390-1411.

Wei, G., Liu, H., Zhang, R., Zhu, Y. and Xu, X. (2016). Mass concentrations of polychlorinated dibenzo- $p$-dioxins and dibenzofurans (PCDD/Fs) and heavy metals in different size fractions of hospital solid waste incinerator fly ash particles. Aerosol Air Qual. Res. 16: 1569-1578.

Wu, Y.L., Lin, L.F., Hsieh, L.T., Wang, L.C. and ChangChien, G.P. (2009). Atmospheric dry deposition of polychlorinated dibenzo- $p$-dioxins and dibenzofurans in the vicinity of municipal solid waste incinerators. $J$. Hazard. Mater. 162: 521-529.

Xu, M.X., Yan, J.H., Lu, S.Y., Li, X.D., Chen, T., Ni, M.J., Dai, H.F., Wang, F. and Cen, K.F. (2009). Agricultural soil monitoring of $\mathrm{PCDD} / \mathrm{Fs}$ in the vicinity of a municipal solid waste incinerator in Eastern China: Temporal variations and possible sources. J. Hazard. Mater. 166: 628-634.

Xu, P., Tao, B., Li, N., Qi, L., Ren, Y., Zhou, Z., Zhang, L., Liu, A. and Huang, Y. (2013). Levels, profiles and source identification of PCDD/Fs in farmland soils of Guiyu, China. Chemosphere 91: 824-831.

Yan, F., Zhu, F., Wang, Q. and Xiong, Y. (2016). Preliminary study of $\mathrm{PM}_{2.5}$ formation during municipal solid waste incineration. Procedia Environ. Sci. 31: 475481.

Yu, M.F., Lin, X.Q., Li, X.D., Chen, T. and Yan, J.H. (2016). Catalytic decomposition of PCDD/Fs over Nano- $\mathrm{TiO}_{2}$ based $\mathrm{V}_{2} \mathrm{O}_{5} / \mathrm{CeO}_{2}$ catalyst at low temperature. Aerosol Air Qual. Res. 16: 2011-2022.

Yu, S., Zhang, Q., Yan, R., Wang, S., Li, P., Chen, B., Liu, W. and Zhang, X. (2014). Origin of air pollution during a weekly heavy haze episode in Hangzhou, China. Environ. Chem. Lett. 12: 543-550.

Yu, Y., Zhao, S., Wang, B., Fu, P. and He, J. (2017). Pollution characteristics revealed by size distribution properties of aerosol particles at urban and suburban sites, northwest China. Aerosol Air Qual. Res. 17: 17841797.

Zhang, M., Zhang, S., Zhang, Z., Xu, Z., Feng, G. and Ren, M. (2014). Influence of a municipal solid waste incinerator on ambient air PCDD/F levels: A comparison of running and non-running periods. Sci. Total Environ. 491-492: $34-41$.

Zhang, X., Zhu, Q., Dong, S., Zhang, H., Wang, X., Wang, M., Gao, L. and Zheng, M. (2015). Particle size distributions of PCDD/Fs and PBDD/Fs in ambient air in a suburban area in Beijing, China. Aerosol Air Qual. Res. 15: 1933-1943.

Zhang, X., Zheng, M., Liang, Y., Liu, G., Zhu, Q., Gao, L., Liu, W., Xiao, K. and Sun, X. (2016). Particle size distributions and gas-particle partitioning of polychlorinated dibenzo- $p$-dioxins and dibenzofurans in ambient air during haze days and normal days. Sci. Total Environ. 573: 876-882.

Zhu, J., Xing, J., Tang, H., Lee, W.J., Yan, P., Cui, K. and Huang, Q. (2017). Atmospheric deposition of polychlorinated dibenzo- $p$-dioxins and dibenzofurans in two cities of northern China. Aerosol Air Qual. Res. 17: 2027-2040.

Zhu, Q., Zhang, X., Dong, S., Gao, L., Liu, G. and Zheng, M. (2016). Gas and particle size distributions of polychlorinated naphthalenes in the atmosphere of Beijing, China. Environ. Pollut. 212: 128-134.

Received for review, September 15, 2017 Revised, October 24, 2017 Accepted, October 24, 2017 